Advances in Ecological Research 5, edited by J.B. Cragg. Academic Press, 80s.

All the papers in the volume are of interest to conservation biologists, but that by Dr. R. Daubenmire on "The Ecology of Fires in Grasslands" is the most directly relevant, showing that the effects of fire are by no means always detrimental, in fact many habitats and species depend upon it. In some areas burning increases humus, in others it reduces it; he shows how unwise it is to generalise about this complex subject.

There is no common theme to the papers in this volume but all are stimulating reviews of different aspects of ecology. In "Towards Understanding Ecosystems", Dr. D.M. Gates demonstrates the value of working mathematical models based on physical and biological principles. From an exact appraisal of the factors affecting energy exchange between a single leaf and its environment he proceeds logically and lucidly to means of studying complex matters such as plant competition and succession on a quantitative basis. Dr. Gates believes that one day ecology will be the most challenging of all theoretical disciplines.

The amphibia in Australia are represented only by the frogs and toads. The group is of special interest because several species have become well adapted to life in arid regions; speed in rehydration after drought is shown to be particularly important. In "Ecology, Systematics and Evolution of Australian Frogs", Dr. A.R. Main provides an excellent synthesis. Special attention is given to the fauna of Western Australia with much new information.

Very few thorough long-term studies have ever been made on any ecosystem; that by Professor O.W. Richards, Dr. N. Waloff and Dr. J.P. Dempster and their students at the Imperial College Field Station at Silwood Park is a well-known exception. The study has continued for over twelve years and many aspects of it have been recorded in the literature. In her review "Studies on the Insect Fauna of Scotch Broom" which contains information from unpublished theses, Dr. Waloff provides a much needed synthesis which will be of great value to all interested in prey/predator, host/parasite and competitive relationships.

N.W. MOORE

\title{
Field Natural History: A Guide to Ecology, by Alfred Leutscher. Bell, $\mathbf{£} 3$.
}

The author of this book, in his daily work as senior lecturer in charge of educational services at the British Museum (Natural History), and in his many outside activities, is continuously in contact with school children and their teachers. His book is obviously the result of many years of experience in putting over to them the kind of information that he now shares with a wider audience in a very clear and straightforward way. Far more is included than the title of the book might imply. Part I 'The Organism and its Environment' is, in fact, a generous introduction to both geology and biology, with sections on evolution theory, Mendelism, animal camouflage and warning coloration, parasitism and classification. Part 2 'Major Habitats in Britain' is a useful summary of the main characteristics of woodlands, chalklands, heath and moorland, the sea coast, mountains, freshwater habitats, waste ground, hedgerows, roadsides and fields and man-made habitats. Part 3 'Field Work' sets out I9 projects for practical work based on studies which the author has made in his beloved Epping Forest. There is an epilogue on conservation, 23 valuable appen- 
dices and a very full bibliography. The illustrations are from line drawings by the author.

With all this wealth of useful and interesting information the book would be a valuable manual for the 'older schoolchildren, college students, their teachers and instructors' for whom it was primarily written. It would be a pity if its somewhat high price puts it beyond their reach for there never has been a time when it was more urgent for a population largely divorced from direct contact with the natural environment to be brought back at least to some awareness of its many facets so that they may begin to learn how to use it properly.

JOHN CLEGG

\section{Brief Reviews}

So much has happened in the past ten years that a revised edition of Environmental Conservation (Wiley, 80s) by Raymond Dasmann, one of the ablest expositors in the conservation field today, is very timely. Alas, he has had to point out the widespread deterioration in the environment since he first wrote: 'Today we know that the world we live in is one biosphere, and that, unless we take a global view of environmental problems, our chances for survival are slim. The first edition was launched with hope. Today prayer is more appropriate'.

The Long Bay of Druridge, by Henry Tegner (Frank Graham, Newcastle upon Tyne, 30s) is an enjoyable account of one small stretch of the Northumberland coast by an observant and knowledgeable naturalist who has watched and walked it for nearly 30 years, with observations on seals and whales, mackerel and cod, sharks and shells, lampreys and waders, and many more.

The Nervous System, a Pelican Original (IOs) by Peter Nathan, who is a research neurologist at the National Hospital, Queen Square, London, is a most readable account for the layman of the human nervous system, which of course has nothing to do with "it's me nerves, doctor". It is a pity that animals cannot read it; they might find out why we are so often callous and cruel to them.

\section{ORYX by Airmail}

Overseas members who would like their copies of ORYX sent by second-class airmail are asked to add the appropriate amount to their next annual subscription (£3).

Europe, USSR

Ethiopia, Sudan, Middle East

Africa (other than Ethiopia and

Sudan), Asia, Antarctica, Canada, USA, South America, West Indies

Australasia, Japan, Pacific
3 s $3 d$

$14 \mathrm{~s} 0 \mathrm{~d}$

$16 \mathrm{~s} 8 \mathrm{~d}(\$ 2.00)$

$19 \mathrm{~s} 4 \mathrm{~d}(\$ 2.50)$ 